\title{
No Evidence of Tumor Cell Necrosis Present
}

National Cancer Institute

\section{Source}

National Cancer Institute. No Evidence of Tumor Cell Necrosis Present. NCI Thesaurus. Code C156236.

A morphologic finding indicating the absence of focal or diffuse tumor cell necrosis in a tissue sample. 